\title{
Arthur Waley, Xu Zhimo, and the Reception of Buddhist Art in Europe: A Neglected Source
}

\author{
T. H. BARRETT \\ Emeritus \\ SOAS, London \\ tb2@soas.ac.uk
}

Keywords: Arthur Waley, Xu Zhimo, Anesaki Masaharu, Zen art, translation

DOI: https://dx.doi.org/10.15239/hijbs.01.01.08

Abstract: This paper examines the creation of 'Zen Art' in the Anglophone world. In particular, I examine the celebrated translator Arthur Waley's conceptualization of Zen art, and argue that he wrote an anonymous review of Anesaki Masaharu's 姉崎正治 English-language treatise on Buddhist art and ideals with the help of Xu Zhimo. This overlooked review is an important text to trace the twentieth century discussion and translation of Zen writings on art and aestheticism. While discussing both Anesaki and Waley's respective works on Buddhist art, in addition to Waley's interactions with Japanese Zen writers, I outline the cast of characters and the networks that created a popular concept of 'Zen Art' in the Anglophone world that did not exist in East Asia. 


\section{The Origins of 'Zen Art'}

7 he context into which I wish to introduce the neglected source referred to in my title concerns the reception of Buddhist Art in Europe, but the specific focus is on the creation of 'Zen Art' in the Anglophone world, a phenomenon which spans for present purposes not only Europe but in a tangential way North America also. Whether there existed or exists a Zen Art as such in the Japanese world or its equivalent in China I do not know, and the question lies entirely beyond the scope of the remarks that follow. I do however notice that anyone wishing to undertake a study of the links between the Chan tradition and painting in Song China and thereafter does have to take the existence of a notion of 'Zen Art' in English quite seriously, since for about a century the term has had an important degree of currency in Anglophone writing on a topic of this sort. Thus an important new dissertation on Chan figure painting of the thirteenth and fourteenth century is obliged in a brief introductory section to delve back beyond D. T. Suzuki and his seminal discussion of Zen aestheticism in his 1938 Zen and Japanese Culture to discuss briefly Okakura Tenshin 岡倉天心 (1862-1913) and Ernest Fenollosa (1853-1908). ${ }^{1}$ A fuller account would however no doubt have to include not only these names but also the first work to allude to the construct 'Zen Art' in its title, namely Arthur Waley, Zen Buddhism and Its Relationship to Art, which appeared in April, 1922. ${ }^{2}$

Here we certainly find some stirring and remarkable passages. For example:

Through Zen we annihilate Time and see the Universe not split up

1 McNeill, 'Narrative Agency', 24-31. Cf. Suzuki, Zen, 27-this is the revised version of the 1938 book that if anything has had even wider influence. Another dissertation reconsidering this territory from a slightly different angle, and with considerably less attention to the existing historiography of the topic, is Paul, 'Wandering Saints'.

2 For a full bibliographic record of Waley, Zen Buddhism, see Johns, A Bibliography, 27-28. 
into myriad fragments, but in its primal unity. Unless, says the Zen aesthetician, the artist's work is imbued with this vision of the subjective, non-phenomenal aspect of life, his productions will be mere toys.

Or,

Perhaps it is not even very important that the artist himself should have a sound aesthetic; but it is of the utmost importance to the artist that the public should have some notion of the conditions under which art can be produced-should have some key to the vagaries of a section of humanity which will in any case always be found troublesome and irritating. Such a key Zen supplied, and it is in the language of Zen that, after the twelfth century, art is usually discussed in China and Japan $[$ sic $] .^{3}$

The contribution of Arthur Waley (1889-1966) to translation from Chinese and Japanese is well known, and during the last four decades of his life his reputation rested largely on his achievements in these fields. ${ }^{4}$ Much less well known is his contribution to the discourse of 'Zen Art' in this slim volume and in a second work from September 1922, An Introduction to the Study of Chinese Painting, that incorporates much of the material in the earlier April book, though this book, including the passages just quoted, has been examined by John Walter de Gruchy in a monograph dealing with Waley's contributions to the appreciation of Japanese culture in the United Kingdom and beyond. In fact his discussion starts with a slightly earlier publication by Waley from 1921, The Nó Plays of Japan, wherein a Zen training is posited as the key factor in the

3 Waley, Zen Buddhism, 22. No documentation is offered for these assertions, which do not seem to have been confirmed by subsequent research. See also below, note 16 .

4 Note for example Arberry, British Orientalists, 46: 'It is hardly necessary to introduce to the British public the name of Arthur Waley, whose delicate renderings of Chinese and Japanese poetry have enriched English literature and proved once more that an orientalist can also be a poet'. 
composition of the plays translated. ${ }^{5}$ De Gruchy, in correcting this misunderstanding, tries to uncover the origins of Waley's assertions on the cultural importance of Zen, and notes his references in Zen Buddhism and Its Relationship to Art to Okakura and to Nukariya Kaiten 忽滑谷快天 (1867-1934), author of a pioneering work on Zen in English. ${ }^{6}$ For some further influences on Waley he then turns to some early writers on Zen treated in a key study of its twentieth century Anglophone rhetoric by Robert Sharf. In fact this classic essay, which mentions Waley only in passing as a minor accessory to the promotion of the idea that Zen influence embraced the whole of Japanese cultural life, does not actually attempt to sketch the background to Waley's ideas at all, referring only to his 'considerable familiarity with classical Zen scriptures'. This is something that Waley certainly already claimed in his first 1922 book, but a claim for which there is at that date no evidence whatsoever. For his assertion that in his little account of Zen and art he was primarily ('Most of this paper...') drawing on a recently published collection that indeed contained over one hundred and fifty hitherto scarcely available Chinese Chan texts is simply hardly credible, in view of his rather tentative knowledge of Chinese at this point. ${ }^{8}$ Indeed, to all appearances, at this stage Waley's reach far exceeded his grasp, for in his 1921 survey of the Buddhist context of medieval Japanese drama at any rate we are solemnly assured that Amidists study and chant the title of the Lotus Sutra!?

5 Waley, The Nō Plays, 27-28.

6 De Gruchy, Orienting Artbur Waley, 114. The reference is to the bibliography in Waley, Zen Buddhism, 30.

7 See Sharf, 'The Zen', 156, notes 82 and 133.

8 Waley, Zen Buddhism, 30, alleges in these words that he made use throughout of the Chan section in the supplement to the Kyoto Canon, which may have been available at the British Museum (certainly nowhere else), but he cites absolutely nothing from it. By 1922 he had certainly made some progress in Chinese, but the language of Chan texts is tricky, full of colloquialisms from a long lost stage in the development of the spoken language.

9 Waley, The Nō Plays, 58. 
If we look more closely, moreover, Waley does not even pretend to derive his ideas about Zen and art from Nukariya, but only his notions of Zen itself: a reading of Nukariya's The Religion of the Samurai does not reveal to my eye any mention of art at all, though there is quite a bit about Zen and Nature. ${ }^{10}$ As the title indicates, most of its author's efforts are actually directed at asserting a link between Zen and the recently invented tradition of Bushidō, the Way of the Warrior, a link that was certainly for its part open to historical question. ${ }^{11}$ By contrast Okakura, in his books The Ideals of the East of 1903 and The Book of Tea of 1906, certainly does talk about Zen and culture. In the former for example he states at one point 'But it required the artists of Ashikaga, representing the Indian trend of the Japanese mind released from Confucian formalism, to absorb the Zen idea in all its intensity and purity'. ${ }^{12}$ Note here the easy combination of India, Confucius and Japan in a single sentence. In the latter book we read as another example: 'Since Zennism has become the prevailing mode of thought, the art of the extreme Orient has purposely avoided the symmetrical as expressing not only completion, but repetition'-a rather sweeping and of course totally undocumented statement that would likewise seem to cover China and Korea as well as Japan. ${ }^{13}$ In general such modes of expression are not atypical for him: despite the passages quoted, Okakura emerges overall by contrast with Nukariya as a remarkably non-sectarian figure, concerned with the cultural position of Japan within a broad context as a new Asian force, rather than with Zen alone as a potential specific counterbalance to Christianity. ${ }^{14}$

Of course, in spite of this difference in overall objectives, it is true that Waley may have, as he claimed, extrapolated a concept of

\footnotetext{
10 Nukariya, The Religion, 72-74.

11 Benesch, Inventing the Way, 137-40-Nukariya himself appears on 140.

12 Okakura, The Ideals of the East, 178-79.

13 Okakura, The Book of Tea, 95.

14 For Okakura in the context of an emerging Japanese Orientalism, see for example Tanaka, Japan's Orient, 13; there is a growing literature on this fascinating figure.
} 
Zen art from Okakura's writings, even if nothing precisely answering to that description is clearly articulated there. Another source, however, that does use the term 'Zen Art' and has plenty to say, just like Okakura, about its place in Japanese civilisation, whilst packing in a great deal of what would have appeared to readers of the period to have been both revelatory and reliable information about the details of the art history of East Asia, did appear a few years later, and was probably known to Arthur Waley in a revised edition improved by the work of a pioneering European scholar in this field, Raphaël Petrucci (1872-1917). ${ }^{15}$ This was the Epochs of Chinese and Japanese Art, by Ernest Fenollosa, already mentioned above. ${ }^{16}$ Fenollosa was better informed about East Asian culture than many have given him credit for, but his main Buddhist influences seem to have been from the Tendai and Kegon schools rather than Zen. ${ }^{17}$ The actual phrase 'Zen Art' occurs only in a passage of historical narration explaining the potential of Kamakura period art to exert an influence somewhat later in the sixteenth century, and certainly

15 The scholarship of the Naples-born, French-educated and at this point Brussels-based Petrucci, though important in its day, was later eclipsed by the achievements of the great figures of French Sinology, but for an overview of his life and work, see the notice by Eric Lefebvre.

16 Waley does not mention Fenollosa in his April book on Zen art, but does mention the first edition in his September publication An Introduction to the Study of Chinese Painting, 253. Petrucci's revision, which mainly affected the spelling of Japanese, appeared in 1913, so I suspect Waley read this edition, though for the passages in question (below, note 18) the pagination is the same. In Waley's September book, which was reissued by the publisher unaltered in 1958, the passages from Zen Buddhism cited above at note 3 may be found on 226-27. Although as we shall see below Waley's assertions about his sources for this book may be open to a degree of question, it would be wrong therefore to assume that his book did not represent a major advance: see Sullivan, 'Reaching Out', for a very positive assessment of its contribution.

17 Note the vindication of his scholarship - with due regard for its inevitable limitations at such an early stage of East-West contacts - in Fenollosa and Pound, The Chinese Written, 19-25. 
does not either announce or recapitulate the notions encapsulated in the term in any obvious way so as to form a discrete theme of the book. But again it may have been possible for Waley to extract from this source more information to bolster an idea already derived from a reading of Okakura. ${ }^{18}$

Now it is not the intention here to pin down the precise development of the approach to painting subsumed in the phrase 'Zen Art'. That would be a much larger project, and one that I feel no call to undertake. To repeat, all that is offered here is an account of some hitherto overlooked evidence for the process whereby the term was introduced to wider currency, tucked away in a somewhat unlikely place. The full background picture that lies behind Zen Buddhism and Its Relationship to Art is a complex one, and would include for example the influence on Waley of his superior at the British Museum, the poet and art critic Laurence Binyon (1869-1943). Binyon's most influential work on Asian art, The Flight of the Dragon, first appeared in 1911, when its author knew nothing of East Asian languages. While the sources of its author's ideas in this study remain to be explored, it certainly remained highly influential through constant reprintings in a way that Waley's book did not. ${ }^{19}$ Binyon's essay does in fact mention Zen, though in a single passage, anticipating Nukariya, in which through comparisons with William Wordsworth (1770-1850) and George Meredith (1828-1909) it is argued that 'to the Zen votaries the contemplation of the life of nature was, above all, an effort towards the realisation of one's self. ${ }^{20}$

But to sum up for the present, Zen Buddhism and its Relationship to Art emerges as misleading to a fault in its description of the sources on which it draws. In the one page bibliography, wherein the 'European' language works drawn upon are named, apart from the two Japanese authors already discussed, we are only treated to a

\footnotetext{
18 Fenollosa, Epochs, 98.

19 Hatcher, Laurence Binyon, 146 and 161-62, shows that the reaction to Binyon's work was immediate and strongly divided, but does not explore the content of work itself in any detail.
}

20 Binyon, The Flight of the Dragon, 37-38. 
quotation on the topic of Bodhidharma from the redoubtable Jesuit authority Father Léon Wieger (1856-1933), the purpose of which seems mainly to illustrate what Waley terms his 'robust and likeable bigotry'. Among 'Native' [sic] sources we find, beyond the assertion noted above that Waley's narrative is mostly based on extensive reading in Chinese, one reference each to a Japanese article, to an early Chinese gazetteer, and to a Japanese edition of the Chan collection The Blue Cliff Record (Biyan lu 碧巌録). ${ }^{21}$ For a more reliable estimation of the materials on which he drew, his An Introduction to the Study of Chinese Painting, which appeared a few months later, turns out to be much more revealing. Once again the bibliography assures us with regard to secondary works in all languages, which includes mention of both Okakura and Fenollosa, that the author has not used the books as 'sources', and that their listing should not be taken as any indication of their usefulness or reliability. Again, it is stressed that 'Most of my information has been drawn either direct from Chinese texts or from citations of such texts in Japanese works'. ${ }^{22}$ Yet a footnote in this volume does show that Waley was familiar with a publication by a Japanese writer in English somehow overlooked in the bibliography, who turns out to have been rather eloquent on the topic of 'Zen Art', and it is to this scholar's work that we should now turn. ${ }^{23}$

\section{Anesaki Masaharu (1873-1949)}

Anesaki Masaharu is scarcely an obscure name in the study of Asian religion. By the time that Arthur Waley cited him, he had established through travel to India combined with study in Germany a worthwhile

21 The Japanese edition is by 'Soyen’ [sic], i.e. Shaku Sōen 釈宗演 (18601919), one of the early propagators of Zen in the West (and patron of D. T. Suzuki) treated in the study by Sharf, 'The Zen', 7.

22 Waley, An Introduction, 253.

23 Waley, 94, note 1: the citation, given below in note 26 , is by a very abbreviated title. 
reputation in Indology, and his combination of this expertise with a firsthand familiarity with American Unitarianism had also allowed him to begin a career in the broader field of the study of religion. ${ }^{24}$ Throughout his life he remained an adherent of the Nichiren tradition of Japanese Buddhism, and so despite the breadth of his interests, in some ways he is the very last person one might suspect of having promoted an interest in Zen in relation to art. The book cited by Waley belongs, however, to a distinct phase in his life from 1913 to 1915 when for two academic years he held the position of Professor of Japanese Literature and Life at Harvard University. During this time he turned from his broader interests to the promotion of a knowledge of Japan, and to this end composed no less than five monographs in English based on lectures given at Harvard and elsewhere at the time, though some of these were not published until considerably later. ${ }^{25}$ The one noticed by Waley was one of the first to appear, namely Buddhist Art in Relation to Buddhist Ideals, with Special Reference to Buddhism in Japan. ${ }^{26}$

Waley was of course not the first to respond to its publication. One notice was, however, by someone who later became the chief architect of the Nazi policy of looting art collections throughout Europe, so here his name is not mentioned, nor is his review discussed. ${ }^{27}$ But another, published in Shanghai in 1917 to greet the London, 1916, edition put out by John Murray, a review signed simply 'RFJ', can only be by Reginald Fleming Johnston (1874-1938), future tutor to the last emperor of China and Professor of Chinese at SOAS, and by this point for many years a serious student of Buddhism. ${ }^{28}$ This assessment

24 For Anesaki's links with Japanese adherents of American Unitarianism promoting the study of comparative religion, see Mohr, Buddhism, Unitarianism, 98-100.

25 For a brief survey, see Isomae and Fukasawa, Kindai Nibon, 68-70.

26 Waley cites Anesaki, Buddhist Art, Plate VI (after 16).

27 Petropoulos, The Faustian Bargain, 55-56.

28 Tarocco, The Cultural Practices, 8-9, comments on his importance in this regard. Unfortunately, the Buddhist aspect of Johnson is only mentioned in passing and inaccurately in Lamont-Brown, Tutor to the Dragon, 40. 
of Anesaki's work is both lengthy and sympathetic, opening with a reminder that readers of English might already find contributions by Anesaki in their language in the volumes that had already appeared at that point of the Encyclopedia of Religion and Ethics edited by James Hastings (1852-1922). ${ }^{29}$ The penultimate page of the review draws particular attention to what its author terms 'a remarkably fine delineation of the Zen (Chinese Ch'an) school of Buddhist thought'. In particular the reviewer singles out two quotations from Anesaki's account: 'as a method of achieving a union of the individual with the cosmic spirit, Zen training manifested itself in art of a transcendental kind', and 'there is in Japan hardly a form of thought or activity that Zen has not touched and inspired with its ideal of simple beauty'; and as it happens the pages from which these quotations are taken are even headed in capitals 'Zen Art'. ${ }^{30}$

Anesaki does seem a slightly unusual figure as an apostle for the Zen art cause. True to his own beliefs, for example, he follows his account of Zen with some further remarks stressing the links between the art of Kōetsu 光悦 (1558-1637) and the Nichiren tradition. ${ }^{31}$ His bibliography, which is extensive, includes Okakura and Fenollosa, and also Nukariya, but also many other writers. ${ }^{32}$ In discussing Zen he doesunlike Waley-cite, in what are apparently his own translations, primary materials written by the medieval Japanese masters Keizan 瑩山 (1268-1325) and Dōgen 道元 (1200-1253), but he does not vaunt a command of the whole Chan and Zen literary tradition. ${ }^{33}$ Yet no doubt writing under some pressure in a language not his own - to judge from what we know of his relatively short time at Harvard-he seems to have produced a synthesis of contemporary ideas about Zen and art deemed suitable at least for the Anglophone world that struck his Scottish reviewer at least as impressive. Given that we know that Waley read

29 For these contributions see Isomae and Fukasawa, Kindai Nibon, 404. The review by RFJ is in Journal of the North China Branch.

30 Anesaki, Buddhist Art, 53.

31 Anesaki, 60.

32 Anesaki, 65-67.

33 Anesaki, 50, 51. 
his work at least by the time that he published his second 1923 volume on painting, could it be that a familiarity with Anesaki lies also behind his less bibliographically forthcoming, slightly earlier monograph on Zen and art? Or was this innovation in his avowed sources simply the outcome of a further summer of diligent reading?

Now there are some indications that the second book went through a gestation period of several years. From December 1920 up to December 1921 Waley published in the Burlington Magazine a series of nine articles under the general title 'Chinese philosophy of Art' that covers a number of Chinese critics who appear again in the Introduction to the Study of Chinese Painting; one or two other articles published in 1922 might also be construed as preparatory studies pointing towards the 1923 volume. ${ }^{34}$ Yet there is nothing listed in the standard bibliography of Arthur Waley for this period that would seem to indicate that he was preparing to publish on Zen and art at all. This, however, is not the full story. For in 1921 a note appeared in the Bulletin of the School of Oriental Studies directed at what can only be described as a gross error that may be found in Anesaki's book. Plate XXX, which is used to introduce the discussion of Zen that follows in the fourth chapter, is a painting of Bodhidharma upon which is written a poem that is translated, on the facing page giving details about the work, as follows: ${ }^{35}$

Oh thou solitary sage! Hast thou a skin?

Then surely blood is streaming in thee.

Canst utter words?

Given a flower, what wouldst do?

Thy lips would be a drum, thy chin a banner, eh?

If this seems mysterious, it is because the translation is in fact utter nonsense. The translator has simply failed to notice that the inscription, instead of being written from right to left, as one might expect, must actually be read from left to right. As the note in the Bulletin

\footnotetext{
34 Johns, Bibliography of Arthur Waley, 88-89.

35 Anesaki, Buddhist Art, plate before 47.
} 
points out, when read that way a perfectly intelligible comment on Bodhidharma emerges, describing his famous encounter with Emperor Wu of the Liang dynasty, tentatively rendered there in an alternative version as follow:

Saying nothing but 'Don't know', he drummed his lips on his teeth; For how could he turn his Indian speech into Chinese?

If he is to cause old Hsiao (i.e. the Emperor) to have any blood under his skin,

He will have to drive him across the desert sands. ${ }^{36}$

Now if the mistake was made by Anesaki, it seems hardly credible. First, the direction of the inscription seems clearly marked by the writer's signing off at the end, on the right—-though perhaps the whole last line could have been construed as the initial title plus author. But secondly, a few pages later an inscription that may be found on Plate XXXIX, a depiction of Hanshan 寒山 and Shide 拾得 from fifteenth century Japan, follows exactly the same left-right pattern, and here Anesaki, or whoever was responsible, translates in due accordance with the actual sense of the lines, without any trouble. But quite possibly the Plate XXX inscription was not translated by him. First, the extremely stilted diction does not accord with his style elsewhere in translating other inscriptions. Secondly, he acknowledges extensive editorial help in a preface dated May, 1914, at the end of his first academic year at Harvard, from Mr. J. E. Lodge of the Boston Museum of Fine Arts, 'Assistant Curator in Charge of the Department of Chinese and Japanese Art, who has done everything for me in selecting material, in revising the manuscripts, and in supervising the publication' ${ }^{37}$ Of course John Ellerton Lodge (1878-1942), son of Senator Henry Cabot Lodge (1850-1924) and eventually director of the Freer Gallery in Washington, may not have been the translator either, if perhaps he sub-contracted some of his editorial work, or otherwise availed himself of an earlier translation effort. The painting itself, attributed to Pumen

\footnotetext{
36 Anonymous, 'Mr. Anesaki and a Zen poem', 171-72.

37 Anesaki, Buddhist Art, viii.
} 
Wuguan 普門無關 (1201-1281), with its inscription by Mieweng Wenli 滅翁文禮 (1167-1250), has long been considered significant and has attracted a fair amount of scholarship, so perhaps in future it may be possible to identify the first Englishing of its Chinese text. ${ }^{38}$

But whoever was responsible for the mistranslation, there is only one problem with connecting the note correcting the translation to Waley and thereby documenting his prior knowledge of Anesaki's work when writing his own account of 'Zen Art'. The note is unsigned.

\section{Who wrote the note?}

The lack of any indication of authorship in the Bulletin of this period or indeed later is, it must be said, highly anomalous, even for a short entry like this in the 'Notes and Queries' section in which it may be found. It does not read like a deliberately anonymous attack, though an attack it certainly is. The piece ends 'The version which I have given must, I think, come fairly near to being right. That of Mr. Anesaki is perhaps the least fortunate attempt to expound Buddhist literature which has ever got itself into print'. Might the omission have been accidental? If so, there is no subsequent correction published in a later issue. But again, the early issues of the Bulletin are not burdened with corrigenda. One of its problems in these early days may have been that its editor was also the Director of the School, Sir Edward Denison Ross (1871-1940), a man kept extremely busy by the failure of the government to fund adequately the institution it had just brought into being. So it is not inconceivable that an accidental omission was allowed to stand.

The note is preceded by four others on East Asian and Buddhist topics. The first three are by Arthur Waley, but the last is by the great Buddhologist Louis de La Vallée Poussin (1869-1938), though the following final note is unlikely to be by him, since while he could

38 For a short listing of relevant publications, see Cahill, An Index, 318. For a translation of the inscription by Suzuki, see his Essays in Zen Buddhism, plate opposite 304 . 
certainly read Chinese, he showed no interest whatsoever in Zen. ${ }^{39}$ Waley's authorship is, by contrast, intrinsically quite likely. Ross had become a friend of his when they had both been working at the British Museum, and for contributions and reviews to the Bulletin on China related topics he looked to Waley ahead of anyone else, and certainly ahead of any academics, since at this point he had no one on his staff who could offer scholarly work using Chinese. ${ }^{40}$ The professorship of Chinese was in abeyance from 1914 to 1925-hence Waley notes in his introduction to his second book on painting that the sort of Chinese required for the study of painting was at the time simply not taught in London-so in this area Ross turned to others, including primarily Waley but also Lionel Giles, likewise at the British Museum, and occasionally on Buddhist topics extending to Chinese, La Vallée Poussin. ${ }^{41}$ In particular Ross, in the second issue of the journal in 1918, had combined with Waley in reviewing an encyclopedia on things Chinese, and in this he left it entirely to Waley to comment on the entries on painting and poetry. ${ }^{42}$ The absence of any listing of the piece in Waley's standard bibliography is not a problem, since the author of that work did not work from records kept by the writer himself, and so passes over for example short anonymous notices published in the Times Literary Supplement, as I have established elsewhere. ${ }^{43}$ At least one short piece under Waley's name is also missed. ${ }^{44}$

There is, however, one potential clue to the identity of the author of the anonymous 1921 notice contained within the body of the work, in the antepenultimate sentence, just before the final thrust, already quoted above. With the sentence before it, the close of the piece begins 'The inscription is in cursive. Several characters

39 For a brief summary of his major interests with further references, see de Jong, A Brief History, 41-42.

40 For Ross and Waley, note de Gruchy, Orienting Arthur Waley, 69, 73.

41 For the professorship, see Twitchett, Land Tenure, 10; Waley's comment is in Introduction to the Study of Chinese Painting, 8, n. 1.

42 This review is listed as E1 in Johns, Bibliography of Artbur Waley, 109.

43 Barrett, 'Arthur Waley', 116-21.

44 Waley, 'A Hundred and Seventy', 162. 
puzzled me, and without the assistance of Mr. Hsü, of Cambridge, I could not have made sense of it'. Now in 1921 the number of persons bearing the name $\mathrm{Xu}$ (to convert to pinyin) and resident in Cambridge, and especially those bearing the name $\mathrm{Mr}$. Xu who were capable of advising on thirteenth century calligraphy, would have been severely limited. One of them, however, is now very well known, and indeed his own calligraphy has been collected and published in this century by a famous art publisher in China in five lavish volumes. ${ }^{45} \mathrm{But}$ if the wider world knows anything of $\mathrm{Xu}$ Zhimo 徐志摩 (1897-1931) it is that he left Cambridge twice. So famous is the poem he composed on the second occasion that it has now been partially inscribed in close proximity to the bridge over the River Cam in King's College, to which he had been affiliated, for the benefit of tourists, and a slim bilingual volume of his poems has been issued in Cambridge for those anxious not to leave the town themselves without a literary souvenir. ${ }^{46}$ The exact chronology of these iterated departures is not spelled out in the introduction to this volume, but fuller accounts of Xu's life make it clear that after arriving in London from New York in 1920 he had certainly transferred to Cambridge the following year, and that after a visit to Germany he had returned once more, before leaving for China in late $1922 .{ }^{47}$ His signature is even preserved with that of an eminent visitor, the educator Cai Yuanpei 蔡元培 (1868-1940), in the Visitor's Book of the University Library, Cambridge, for 11 May $1921 .{ }^{48}$ Part of the first sojourn was actually spent with his wife of the time, Zhang Youyi 張幼儀 (1898-1989), in Sawston, near Cambridge, but

45 Wu, Xu Zhimo moji.

46 The poem in question is of course included in this opuscule, Chiang, $X u$ Zhimo, 26-27.

47 The first chronology of $\mathrm{Xu}$ to appear already makes the basic facts clear, though the author does not seem concerned to distinguish life in Cambridge from life in London, perhaps not unreasonably, given the ease of transport communications by rail between the two places by the 1920s. Chen, Xu Zhimo, 17-25. Xu also visited Cambridge on a couple of subsequent occasions.

48 See Aylmer, 'The Memoirs', 81, Figure 10. 
$\mathrm{Xu}$ at any rate maintained contacts not only in Cambridge but also in London, and in any case Waley could easily have come to his own former college, King's, Cambridge, to seek his assistance. ${ }^{49}$

$\mathrm{Xu}$ certainly had met Waley before his second departure, because in a letter written in February 1924 from China to Charles Kay Ogden (1889-1957), the inventor of Basic English, he mentions him as a correspondent connected with his Cambridge days. ${ }^{50} \mathrm{He}$ also discussed Waley's Chinese translations with the writer Katherine Mansfield (1888-1923) in London in July 1922.51 Waley's own reminiscence of their meeting in London unfortunately is not precisely dated, and comes from $1948 .^{52}$ But it is perfectly possible that they met soon after his arrival in England: Xu after all seems to have very quickly got to know in London Goldsworthy Lowes Dickinson (1862-1932), the Fellow of King's College, Cambridge, who had already proved immensely influential on the young Arthur Waley. ${ }^{53}$

To sum up, then, 'Mr. Hsü, of Cambridge', the interpreter of thirteenth century cursive script, is highly unlikely to be anyone other than Xu Zhimo. After all, in 1922, when his then wife received his letter demanding a divorce, she recalled that she could not but admire his command of calligraphy, whatever her thoughts on the sentiments the document conveyed. This makes it more or less certain that the author of the anonymous note was Arthur

49 Chang, Bound Feet, 110-27, covers Zhang's married life with Xu in Sawston; 146 notes that by the autumn of 1921 after her departure Xu was living alone in Cambridge; her subsequent meeting with $\mathrm{Xu}$ in Germany when he demanded a divorce is also described.

50 Liu, Xu Zhimo, 153; cf. 90, for Waley's letter. Ogden was a close associate of I. A. Richards (1893-1979), though these two admirers of Goldsworthy Lowes Dickinson and of his Chinese interests were at Magdalene College, Cambridge, not King's: cf. Koeneke, Empires, 24.

51 Chen, Xu Zhimo, 25.

52 Waley, The Secret History, 169, reprinting the opening of his January 1948 radio talk 'Blake the Taoist', speaks of 'Some twenty years ago'.

53 Chen, Xu Zhimo, 20; de Gruchy, Orienting Arthur Waley, 38-39. 
Waley. If so, why did the Director of the School of Oriental Studies omit his name, when he had just printed it thrice, other than through sheer inattention? By 1921 Denison Ross had known Waley for eight years, and in later life he certainly looked on Waley as an authoritative figure, who demonstrated a commendable preference for avoiding the dispensation of direct criticism-though in the later stages of his career not everyone warmed to him, even so. ${ }^{54}$ The younger Waley, however, seems to have been somewhat less secure, if my reading of his presentation of bibliographical information is correct, and sometimes his remarks at this period of his life were perhaps characterised by greater vehemence than they needed to be. Did the older man perhaps feel that in his verdict on Anesaki the young Waley had gone a little too far, and so felt it expedient to omit his name from the piece?

In the view of John Walter de Gruchy, Arthur Waley's forays into Zen marked a distinctly unpromising trend in his work, and he was probably fortunate to have turned therefrom to the more substantial and perhaps more culturally profitable task of representing the Tale of Genji in English. ${ }^{55}$ In his later years, too, Waley seems to have forsaken his earlier vehemence for a distinctly reserved style. ${ }^{56}$ Certainly by the time that D. T. Suzuki started to publish prolifically on Zen, Waley had adopted a more measured and cautious tone in discussing his writings. ${ }^{57}$ For the moment

54 For a plainly negative reaction to the mature Waley, see Bernal, Geography of a Life, 219; cf. de Gruchy's comments on the verdict given by Ross on Waley, in Orienting Arthur Waley, 73. For a more positive assessment of Waley by Stella Benson (1892-1933) as 'a kind of Bloomsbury saint-he lives in a cloudy ecstasy of cleverness-and looks like an angel, such a perfect, long-lashed, chaste face', though this is somewhat undermined by a later reference to him 'rather cattily' describing Clive Bell (1881-1964) as a 'buffoon' out of place in the highbrow Bloomsbury world, see Grant, Stella Benson, 244, 255.

55 De Gruchy, Orienting Arthur Waley, 116.

56 Lewis, 'The Silences', 63-66.

57 Barrett, 'Arthur Waley', 117, citing Times Literary Supplement, Thursday August 25, 1927, 579, gives the latter portion of his assessment; the piece opens 
we should just note that if Waley is part of the story of 'Zen Art', then we should not discount the contribution made to his ideas by Anesaki, in addition to earlier writers. As for Xu Zhimo, who found such inspiration from his time in Cambridge, it is no doubt to his credit that in return he did what he could to assist the development of sinology in this country. Of course many of the points made here could do with further investigation. But a search of the Denison Ross papers, while revealing correspondence with a number of important individuals, casts no light on his early links with Arthur Waley, which would have been in any case largely based on face to face interactions; no archives exist concerning the early years of the Bulletin. ${ }^{58}$ Possible annotations in Waley's former books on a copy of Buddhist Art in Relation to Buddhist Ideals, might clarify and confirm the matters raised in this examination of the evidence, but it would seem that that volume, if it exists, is no longer in the United Kingdom. Some of Waley's books arrived through SOAS in the library of Durham University, but their copy of Anesaki does not derive from him but from Walter Perceval Yetts (1878-1957). ${ }^{59}$ Yetts is however unlikely to have penned the anonymous review: he was in 1921 still an amateur student of Chinese art, primarily interested in bronzes and sculpture rather than painting, even if in 1930 he did take up a lectureship in Chinese art at the School of Oriental Studies and shortly thereafter was promoted to a professorship.

'These essays (with one exception) are reprinted, with additions and emendations, from the Eastern Buddhist, the organ of the Eastern Buddhist Society, which exists for the purpose of making Buddhism better known in the West. The tone of the book is accordingly half scholarly, half propagandist'.

58 The correspondence in the six files included in the Denison Ross archive in SOAS, PP MS 8/01/01, reveal contacts with such luminaries as Lord Curzon, Gertrude Bell, Rudyard Kipling and Sir Muhammad Iqbal, but nothing from or about Arthur Waley.

59 Shelfmark PLJ 504 ANE-my thanks to Don Starr of Durham for checking this volume and communicating its provenance to me in a personal communication, July 28, 2016. 
Further researches into the early history of 'Zen Art' are more likely to bear fruit in North America. We know for example that Anesaki and D. T. Suzuki were in correspondence well before his tenure at Harvard, even if the latter does not seem to have publicised either through his own writings or those that he prepared for publication in English the ideas about Zen and art that characterise his essays of the postwar period. ${ }^{60}$ But, in the story of the gradual emergence of this way of looking at the art of China and Japan, it would be wrong to assume that East Asia and the United States were the only actors in the drama. There was certainly a British element, too, as I hope I have managed to convey here.

\section{Bibliography}

Anesaki Masaharu 姉崎正治. Buddhist Art in Relation to Buddhist Ideals, with Special Reference to Buddhism in Japan. Boston: Museum of Fine Arts, 1915.

Anesaki Masaharu 姉崎正治, Isomae Jun'ichi 磯前順一, and

Hidetaka Fukasawa 深澤英隆. Kindai Nibon ni okeru chishikijin to shūkyō: Anesaki Masabaru no kiseki 近代日本における知識人 と宗教: 姉崎正治の軌跡 [Intellectuals and Religion in Modern Japan: The Orbits of Anesaki Masaharu]. Tokyo: Tōkyōdō Shuppan 東京堂出版, 2002.

Anonymous. 'Mr. Anesaki and a Zen poem'. Bulletin of the School of Oriental and African Studies 2, no. 1 (1921): 171-72.

Anonymous [Arthur Waley]. Review of Essays on Zen Buddhism, by Daisetsu Teitarō Suzuki. Times Literary Supplement, August 25, 1927, 579.

Arberry, A. J. British Orientalists. London: Collins, 1943. Aylmer, Charles. 'The Memoirs of H. A. Giles'. East Asian History 13/14 (June/December 1997): 1-90.

60 On Anesaki and Suzuki in America, see Tweed, 'American Occultism', 249-81: 257, note 7, shows that the Buddhist sympathizer Edmunds (18571941) thanked Suzuki for introducing him to Anesaki in a letter of 1904. 
Barrett, T. H. 'Arthur Waley, D.T. Suzuki and Hu Shih: New Light on the 'Zen and History" Controversy'. Buddhist Studies Review 6, no. 2 (1989): 116-21.

Benesch, Oleg. Inventing the Way of the Samurai: Nationalism, Internationalism, and Bushidō in Modern Japan. Oxford: Oxford University Press, 2014.

Bernal, Martin. Geography of a Life. Bloomington: Xlibris, 2012. Binyon, Laurence. The Flight of the Dragon: An Essay on the Theory and Practice of Art in China and Japan, Based on Original Sources. London: John Murray, 1911.

Cahill, James. An Index of Early Chinese Painters and Paintings: T'ang, Sung and Yüan. Berkeley, Los Angeles, London: University of California Press, 1980

Chang, Pang-Mei Natasha. Bound Feet and Western Dress. London: Bantam, 1997.

Chen Congzhou 陳從周. Xu Zhimo: nianpu yu pingshu 徐志摩: 年譜 與評述 [Chronicle of Xu Zhimo with Commentary]. Shanghai: Shanghai shudian chubanshe 上海書店出版社, 2008.

Chiang, Nicole, ed. Xu Zhimo 徐志摩: Selected Poems. Cambridge: Oleander Press, 2012.

de Gruchy, John Walter. Orienting Arthur Waley:Japonism, Orientalism, and the Creation of Japanese Literature in English. Honolulu: University of Hawai'i Press, 2003.

de Jong, J. W. A Brief History of Buddhist Studies in Europe and America. Tokyo: Kōsei publishing, 1997.

Fenollosa, Ernest F. Epochs of Chinese and Japanese Art, Volume Two. London: William Heinemann, 1913.

Fenollosa, Ernest, and Ezra Pound. The Chinese Written Character as a Medium for Poetry by Ernest Fenollosa and Ezra Pound: $A$ Critical Edition, edited by Haun Saussy, Jonathan Stalling and Lucas Klein. New York: Fordham University Press, 2008. Grant, Joy. Stella Benson: A biography. London: Macmillan, 1987. Hatcher, John. Laurence Binyon: Poet, Scholar of East and West. Oxford: Clarendon Press, 1995.

Johns, Francis A. A Bibliography of Arthur Waley. London: Athlone Press, 1988.

Koeneke, Rodney. Empires of the Mind: I. A. Richards and Basic 
English in China, 1929-1979. Stanford: Stanford University Press, 2004.

Lamont-Brown, Raymond. Tutor to the Dragon Emperor: The Life of Sir Reginald Fleming Johnston at the Court of the Last Emperor.

Stroud, Gloucestershire: Sutton Publishing, 1999.

Lefebvre, Eric. 'PETTRUCI, Raphaël'. Institut national de l'histoire de l'art. January 12, 2010. Accessed July 4, 2016. http://www.inha.fr/fr/ressources/publications/publicationsnumeriques/dictionnaire-critique-des-historiens-de-l-art/ petrucci-raphael.html.

Lewis, Naomi. 'The Silences of Arthur Waley'. In Madly Singing in the Mountains: An Appreciation and Anthology of Arthur Waley, edited by Ivan Morris, 63-66. London: George Allen and Unwin, 1970.

Liu Hongtao 劉洪濤. Xu Zhimo yu Jianqiao daxue 徐志摩與劍橋大 學 [Xu Zhimo and the University of Cambridge]. Taibei: Xiuwei shudian 秀威書店, 2007.

McNeill, Malcolm. 'Narrative Agency in Thirteenth-Fourteenth Century Chan Figure Painting: A Study of HagiographyIconography Text-Image Relationships'. Ph.D. dissertation, SOAS University of London, 2017.

Mohr, Michel. Buddhism, Unitarianism, and the Meiji Competition for Universality. Cambridge, MA: Harvard University Asia Center, 2014.

Nukariya Kaiten 忽滑谷 快天. The Religion of the Samurai: A Study of Zen Philosophy and Disciple in China and Japan. London: Luzac \& Co., 1913.

Okakura Kakuzo [sic]. The Book of Tea. London and New York: G. P. Putnam's Sons, 1906.

- - - The Ideals of the East, With Special Reference to the Art of Japan. London: John Murray, 1903.

Paul, Paramita. 'Wandering Saints: Chan Eccentrics in the Art and Culture of Song and Yuan China'. Ph.D. dissertation, Leiden University, 2009.

Petropoulos, Jonathan. The Faustian Bargain: The Art World in Nazi Germany. London: Allen Lane, The Penguin Press, 2000. RFJ [Reginald Fleming Johnston]. Review of Buddhist Art in 
Relation to Buddhist Ideals, by Anesaki Masaharu. Journal of the North China Branch of the Royal Asiatic Society XLVIII (1917): 203-08.

Sharf, Robert H. 'The Zen of Japanese Nationalism'. In Curators of the Buddha: The Study of Buddhism under Colonialism, edited by Donald S. Lopez, Jr., 107-60. Chicago: University of Chicago Press, 1995.

Sullivan, Michael. 'Reaching Out'. In Madly Singing in the Mountains: An Appreciation and Anthology of Arthur Waley, edited by Ivan Morris, 108-13. London: George Allen \& Unwin, 1970.

Suzuki, Daisetsu T. Essays in Zen Buddhism, Second Series. London: Rider, 1950.

- - Z . Zen and Japanese Culture. Princeton: Princeton University Press, 1938.

Tanaka, Stefan. Japan's Orient: Rendering Pasts into History. Berkeley, Los Angeles, Oxford: University of California Press, 1993.

Tarocco, Francesca. The Cultural Practices of Modern Chinese Buddhism: Attuning the Dharma. Abingdon, Oxfordshire: Routledge, 2007.

Tweed, Thomas A. 'American Occultism and Japanese Buddhism: Albert J. Edmunds, D. T. Suzuki, and Translocative History'. Japanese Journal of Religious Studies 32, no. 2 (2005): 249-81. Twitchett, Denis. Land Tenure and the Social Order in T'ang and Sung China. London: SOAS, 1962.

Waley, Arthur. 'A Hundred and Seventy Chinese Poems'. Cambridge Review XL, no. 988 (December 6, 1918): 162.

- - - An Introduction to the Study of Chinese Painting. London: Ernest Benn Limited, 1923.

- - . The Nō Plays of Japan. London: George Allen \& Unwin, 1921.

- - - The Secret History of the Mongols. London: George Allen and Unwin, 1963.

- - - Zen Buddhism and Its Relationship To Art. London: Luzac \& Co., 1922.

Wu Dejian 吳德建, ed. Xu Zhimo moji 徐志摩墨迹 [Xu Zhimo's Calligraphy]. Hangzhou: Xileng yinshe 西冷印社, 2008. 